\title{
Merekonstruksi Arah Politik Hukum Pengembangan Perizinan Panas Bumi untuk Pemanfaatan Tidak Langsung
}

DOI : $10.30595 /$ jhes.v\%vi\%i.9824

\author{
${ }^{1}$ Dara Salsabila, ${ }^{2}$ Abi Radjab Ma'ruf, ${ }^{3} Y u l i n d a$ Adharani \\ ${ }^{123}$ Universitas Padjadjaran, dara17001@mail.unpad.ac.id, abi.m.radjab@unpad.ac.id, \\ yulinda.adharani@unpad.ac.id
}

\begin{abstract}
Abstrak
Sistem birokrasi Indonesia pasca ditetapkannya Peraturan Pemerintah Nomor 24 Tahun 2018 tentang Perizinan Berusaha Terintegrasi secara Elektronik menginginkan adanya integrasi izin agar dapat meningkatkan investasi sehingga proses debirokratisasi dapat dilaksanakan. Adanya sentralisasi Izin Panas Bumi sebagaimana telah diubah menjadi Perizinan Berusaha di bidang Panas Bumi yang dikeluarkan oleh Pemerintah untuk keseluruhan tahapan pengusahaan panas bumi yang melibatkan lebih dari satu cakupan wewenang kementerian secara atribusi dan kemudian didelegasikan kepada Badan Koordinasi dan Penanaman Modal. Sentralisasi ini kemudian menimbulkan permasalahan koordinasi pemerintah dengan pemerintah daerah serta masyarakat. Paradigma lain yang kemudian muncul adalah berkaitan dengan pengesahan UU Cipta Kerja yang mengubah ketentuan UU Panas Bumi dengan adanya klasifikasi izin berdasarkan risiko dan penulis melakukan studi komparatif terhadap pengaturan serupa yang ada dinegara lain seperti Belanda dan Australia. Tujuannya adalah untuk mengambarkan permasalahan perizinan dibidang panas bumi untuk pemanfaatan tidak langsung di Indonesia. Penelitian ini menggunakan pendekatan yuridisnormatif dengan spesifikasi penelitian deksriptif-eksploratif. Pada penelitian mengedepankan Indonesia seharusnya memiliki badan otoritas khusus yang memberikan asessmen penilaian resiko berdasarkan klasifikasi kegiatan usahanya. Asessmen ini kemudian menjadi pertimbangan pemberian izin ataupun persetujuan yang berkaitan dengan lingkungan hidup.
\end{abstract}

Kata-kata kunci : Integrasi; Izin; Lingkungan; Panas Bumi; Pemerintah;

Abstract

The Indonesian bureaucratic system after the enactment of Government Regulation Number 24 of 2018 concerning Electronically Integrated Business Licensing wants 
an integrated permit in order to increase investment so that the debureaucratization process also exists in geothermal permits. Centralization of geothermal permits issued by the government for all phases of geothermal exploitation which involve more that one scope of authority of the ministry by attibution and the delegated to the coordinating board for investment. This centralization then created problems with government coordination with local governments and communities. Another paradigm that then emerged was related to the enactment of the manpower act which changed the provisions of the geothermal law with the classification of permits based on risk and the authors conducted a comparative study of similar arrangements in other countries such as the Netherlands and Australia. The aim is to describe licensing problems in the geothermal sector for indirect use in Indonesia. This study uses a juridical-normative approach with descriptive-exploratory research specifications. In research prioritizing Indonesia should have a specific authority body that provides risk assessment assessments based on the classification of its business activities. This assessment then becomes a consideration for granting permits or approvals related to the environment.

Keywords: Environment; Geothermal; Government; Integration; Permit.

\section{Pendahuluan}

Eskalasi pertumbuhan penduduk dan perekonomian Indonesia berjalan secara inheren dengan peningkatan kebutuhan energi listrik. Penggunaan energi di Indonesia masih didominasi dari energi fosil (tidak terbarukan) sebagai pemenuhan sumber tenaga listrik yang mencapai $60.485 \mathrm{MW}$ atau setara dengan 85,31 persen dari keseluruhan kapasitas energi terpasang nasional dengan urutan batu bara untuk Pembangkit Listrik Tenaga Uap (PLTU) mencapai 35.216 MW atau 49,67 persen dari total kapasitas nasional 70.900 MW. Selanjutnya adalah pembangkit tenaga listrik yang berasal dari bahan bakar gas, yang pada pertengahan tahun 2020 saja menyumbang 20.488 MW atau setara 28,90 persen dan selanjutnya adalah Pembangkit Listrik Tenaga Diesel (PLTD) yang dari Bahan Bakar minyak dengan jumlah 4.781 MW setara dengan 6,74 persen dari kapasitas terpasang. Sedangkan energi baru terbarukan (EBT) berproduksi hanya 10.426 atau 14,71 persen dari total kapasitas terpasang yang terdiri dari Pembangkit Listrik Tenaga Panas Bumi (PLTP) dengan 2.131 MW, Pembangkit Listrik Tenaga Air (PLTA) dengan 6.095 MW dan 2.200 MW yang merupakan gabungan dari pelbagai EBT. Maka dari itu tergambarkan bahwa kapasitas EBT di Indonesia masih 
terbatas sehingga perlu dilakukan upaya diversifikasi sumber energi yang optimum seperti panas bumi untuk menjaga kontinuitas pembangunan dan pengembangan masyarakat sebagaimana diharapkan pemerintah bahwa bauran energi primer EBT tahun 2020 sebesar 13,4 persen dan tahun 2025 sebesar 23 persen (Edlar Usman, 2020).

Secara topografi wilayah Indonesia memiliki potensi pengembangan panas bumi dikarenakan aspek kewilayahan berasosiasi dengan jalur gunung api dan berada di daerah tumbukan lempengan tektonik sehingga terdapat jalur gunung api didaerah pasifik (Pacific ring of fire) yang tersebar di Sumatera, Bali, Jawa Nusa Tenggara Timur, Maluku, Nusa Tenggara Barat, dan Sulawesi Utara. Hal ini kemudian dapat dikembangkan agar energi panas bumi bisa menjadi pusat keunggulan centre of excelence. Akan tetapi tantangan pengembangan energi panas bumi masih sangat besar yakni resiko disisi hulu (lapangan) dari segi penyediaan uap panas bumi dan resiko di hilir dibagian pembangkitan sebab energi ini tidak dapat didifusikan artinya bersifat lokal. Hal kontradiktif terdapat pada pengembangan energi fosil yang hanya memiliki indikator resiko pada bagian pembangkitan sebab bahan bakarnya dapat berasal darimanapun (R Sukhyar, 2020). Selain itu ketergantungan terhadap sumber energi fosil masih tinggi dan signifikan yang ditandai dengan Indonesia sebagai pengimpor net importir Bahan Bakar Minyak (BBM) sehingga rentan berada pada fase fluktuatif dan bergantung pada tendensi global. Pada akhirnya pemerintah pun harus menganggarkan subsidi energi dengan jumlah besar dan meningkat setiap tahunnya bahkan di tahun 2020 anggarannya mencapai Rp 125,34 Trilun, padahal dalam arah kebijakan energi nasional menyatakan bahwa Indonesia harus mengurangi ketergantungan terhadap energi fosil yang nilai keekonomiannya terus meningkat sehingga membebankan perekonomian dan juga tidak ramah lingkungan.

Amanat penyelenggaraan pengembangan energi panas bumi selaras dengan prinsip memajukan penggunaan Energi Baru Terbarukan (EBT) dalam Paris Agreement dan Sustainable Development Goals (SDGs) angka 7 (tujuh) yakni terciptanya akses energi yang terjangkau, andal, modern dan berkelanjutan. Hal ini kemudian dikonkretkan pada Pasal 3 ayat 3 huruf a Peraturan Pemeritah Nomor 79 Tahun 2014 tentang Kebijakan Energi 
Nasional yang mengindikasikan adanya kebijakan pendukung salah satunya konservasi energi, konservasi sumber daya energi dan diversifikasi energi, sampai dengan tahun 2050. Selanjutnya pada Pasal 9 huruf f, tahun 2025 peran EBT minimal 23 persen dan tahun 2050 paling sedikit 30 persen, tahun 2025 peran minyak bumi kurang dari 25 persen dan tahun 2050 kurang dari 20 persen, tahun 2025 peran batu bara minimal 30 persen dan tahun 2050 minimal 25 persen dan pada tahun 2025 gas bumi minimal 22 persen dan tahun 2050 minimal 24 persen. Pemerintah-pun melakukan percepatan pengembangan EBT dengan peningkatan kapasitas unit pembangkit listrik tenaga EBT yang ada dan konstruksi baru EBT yang sedang berjalan dalam rencana usaha penyediaan tenaga listrik, mengupayakan menciptakan pasar EBT, meningkatkan aksesibilitas energi kepada masyarakat dengan pendanaan Anggaran Pendapatan dan Belanja Negara (APBN) dan akses pendanaan yang kompetitif, kebijakan pendukung dalam memperbaiki tata kelola percepatan Energi Baru Terbarukan dan Konservasi Energi (EBTKE).

Pengembangan energi panas bumi di Indonesia masih mengalami problematika seperti tidak adanya kepastian harga jual listrik dan harga rendah oleh PT Perusahaan Listrik Negara (PLN) yang hanya sebesar US\$0,97 per kwh dengan harga jual uap 3,7 cents US\$kWh sampai dengan 3,8 cents US\$/kWh yang jika dikomparasikan dengan harga jual listrik adalah 4,20 cents US\$/kWh hingga 4,44 cents US $\$ / \mathrm{kWh}$ dengan peningkatan 1,5 persen per-tahun (Sjafra Dwipa, 2015) padahal investor akan mengeluarkan biaya investasi yang besar dari tahap eksplorasi hingga pemanfaatan. Bahkan pada tahap survei pendahuluan memiliki resiko pengembangan hingga 95 persen, eksplorasi 90 persen, pengeboran eksplorasi 50 persen, studi kelayakan 45 persen, eksploitasi 45 persen sampai 20 persen dan pemanfaatan tidak langsung mencapai 20 persen hingga 10 persen (Ida Nuryatin Finahari, 2020). Dengan harga yang kurang kompetitif dengan internal rate return yang tidak pasti sebab pengusaha harus berhadapan dengan high cost dan high risk tersebut maka berdampak kurang berkembangnya iklim investasi dan pengembangan panas bumi. Hambatan lainnya seperti masalah birokrasi seperti perizinan yang rumit sebab melibatkan multi sektor kementerian dan terdapatnya kewenangan pusat dan daerah yang berbeda sehingga memicu terjadinya tumpang tindih penegakan hukum. Misalnya saja pada tahap survei 
pendahuluan yang dilakukan oleh PT Indonesia Power di Desa Karyawangi, Kecamatan Parongpong, Kabupaten Bandung Barat pada Desember 2014 yang hingga sekarang tidak dilanjutkan dengan alasan yang bahkan tidak diketahui oleh masyarakat dan pemerintah daerah. Hal ini menjadi catatan buruk adanya resentralisasi Izin Panas Bumi yang pada implementasinya kontradiktif dengan semangat partisipasi, demokrasi dan transparansi.

\section{Metode Penelitian}

Jenis penelitian yang penulis gunakan adalah kualitatif dengan menggunakan sumber data primer dan sekunder. Sumber data primer didapatkan dari hasil wawancara mendalam yang dilakukan penulis. Sedangkan sumber data sekunder diperoleh dari peraturan perundangundangan, buku, artikel ilmiah, surat kabar dll yang memiliki hubungan dengan bahan hukum primer untuk mendukung propses analisis bahan primer. Teknik pengumpulan data yang digunakan adalah dengan observasi secara langsung dan wawancara. Adapun metode pendekatan yang digunakan dalam penulisan ini adalah yuridis normatif. Pendekatan yuridis normatif merupakan pendekatan penelitian hukum yang berkaitan dengan suatu penerapan ketentuan normatif secara aktual di masyarakat. Spesifikasi penelitian ini adalah deskriptif-eksploratif yang menekankan penggambaran realistis tentang kondisi kebijakan perizinan panas bumi untuk pemanfaatan tidak langsung di Indonesia, sedangkan spesifikasi penelitian eksploratif bertujuan untuk menggali secara holistik keadaan yang terjadi secara obyektif di masyarakat, sehingga dapat diketemukan permasalahan atas suatu implementasi norma yuridis.

\section{Hasil dan Pembahasan}

Dalam pemanfaatan tidak langsung atau (indirect use) panas bumi menggunakan Pembangkit Listrik Tenaga Panas Bumi (PLTP) yang dapat dioperasikan hingga 95 persen dari kapasitas terpasang sampai lebih dari 30 tahun (Ida Nuryatin Finahari, 2020). Menilik pada cadangan potensi panas bumi di Indonesia dapat menghasilkan 27.000 megawatt atau setara dengan 40 persen dari total cadangan dunia namun yang baru dimanfaatkan hanya 1.179 megawaat saja atau sekitar 6 persen dari total cadangan. Maka dari itu 
Pemerintah melakukan perencanaan proyek 350.000 megawatt dalam upaya peningkatan ekonomi nasional sebagaimana terdapat dalam Rencana Usaha Penyediaan Tenaga Listrik (RUPTL) pada tahun 2015 sampai dengan 2024 sehingga diproyeksikan setiap tahun PLTP harus meningkatkan produksi sebesar 7.000 MW.

Dari sisi pelaku usaha pengembangan energi panas bumi untuk pemanfaatan tidak langsung memiliki peluang besar sebab energi ini dapat diperbaharui dengan panas yang akan terus dipancarkan oleh bumi dari intinya sedangkan energi fosil akan berkurang dan habis, kedua, energi ini tidak menghasilkan emisi yang besar sehingga ramah lingkungan dan bersih meskipun diantaranya tetap mengeluarkan sulfur dioksida, oksida nitrat dan partikulat yang kecil, PLTP dapat dioperasikan dalam jangka panjang apabila resevoir dikelola baik dan energi ekstraksi dapat seimbang dengan batuan untuk memperbaharui panasnya, lahan yang diperlukan pun cenderung lebih sedikit dibandingkan PLT lainnya. Akan tetapi panas bumi juga memiliki kekurangan diantaranya rekayasa teknologi operasional hingga saat ini masih harus diimpor, biaya investasi yang tinggi, belum dapat bersaing secara keekonomian daripada energi fosil, dan permasalahan alih fungsi lahan yang menimbulkan resistensi dimasyarakat, selain itu adanya urgensi transisi energi fosil ke EBT sebab dalam penggunaan energi fosil akan melalui tahapan pembakaran yang menghasilkan karbondioksida dan pada dampak yang lebih lama akan serupa dengan efek rumah kaca yang bisa memerangkap panas sehingga atmosfer akan menaahannya dan menyebarkan panas keseluruh atmosfer dan jumlahnya semakin berkurang dengan pemakaian yang terus meningkat. Sudah menjadi kewajiban bersama untuk melakukan transisi energi yang lebih ramah lingkungan untuk kelangungan kehidupan manusia dalam kerangka pembangunan berkelanjutan. Isu pencemaran dan/ atau kerusakan lingkungan hidup tidak menjadi isu tunggal terhadap transisi energi EBT terutama panas bumi di Indonesia. Berbagai permasalahan lainnya seperti hambatan regulasi, kebijakan bahkan birokrasi menjadi batu sandungan terhadap pengembangan panas bumi. Dalam penelitian ini penulis akan berfokus pada aspek kebijakan perizinan panas bumi untuk pemanfaatan tidak langsung.

Menurut Spelt dan Ten Berge izin diartikan sebagai bentuk persetujuan 
penguasa yang untuk keadaan tertentu menyimpang dari ketentuan larangan dalam peraturan perundang-undangan atau (izin dalam arti sempit) (Philipus M. Hadjon, 1993), sedangkan menurut Sjahran Basach menyatakan izin adalah tindakan hukum administrasi bersegi satu dalam proses implementasi peraturan perundang-undangan berdasarkan syarat-syarat dan prosedur yang telah ditetapkan (W.F Prins dan R Kosim Adisapoetro, 1987). Maka dari itu untuk melakukan suatu usaha dan/atau kegiatan usaha maka memerlukan izin termasuk dalam proses pengembangan panas bumi. Berdasarkan Pasal 1 angka 4 Undang-Undang Nomor 21 tahun 2014 tentang Panas Bumi (UU Panas Bumi) menyatakan Izin Panas Bumi (IPB) merupakan izin melakukan pengusahaan Panas Bumi untuk pemanfaatan tidak langsung pada Wilayah Kerja tertentu. Dalam Undang-Undang Nomor 11 Tahun 2020 tentang Cipta Kerja (UU Cipta Kerja) telah mengubah parsial materi muatan dalam UU Panas Bumi diantaranya mengenai terminologi, menjadi Perizinan Berusaha dibidang Panas Bumi. Akan tetapi secara konsep kedua terminologi ini masih memiliki makna similar, perbedaannya adalah pada nomenklatur badan dan/ atau pejabat pemerintahan yang berwenang menyelenggarakan perizinan. Dalam UU Panas Bumi menyatakan Izin Panas Bumi diberikan oleh Menteri yang dalam hal ini adalah Menteri Energi dan Sumber Daya Mineral (ESDM) secara eksplisit, sedangkan dalam UU Cipta Kerja menyatakan izinnya dikeluarkan oleh Pemerintah dengan pelimpahan wewenang secara delegasi dari Pemerintah Pusat yang dipegang oleh Presiden kepada Menteri.

Penggunaan terminologi pengusahaan yang memiliki kata dasar usaha, dapat dikategorikan sebagai izin usaha dari suatu usaha dan/atau kegiatan dibidang panas bumi untuk pemanfaatan tidak langsung. Usaha merupakan kegiatan yang mengerahkan pikiran, tenaga, atau badan usaha untuk mencapai suatu maksud; kegiatan dibidang perdagangan (dengan maksud mencari untung). Selain itu usaha diartikan sebagai tindakan atau kegiatan apapun dalam bidang perekonomian yang diselenggarakan oleh pengusaha atau individu untuk tujuan mendapatkan keuntungan atau laba (Ismail Solihun, 2006). Maka dari itu perizinan berusaha dibidang panas bumi yang didapatkan untuk dilakukannya pengusahaan dapat dikategorikan sebagai izin usaha. Jika merujuk pada pandangan Sjahran Basach diatas maka segi satu dalam pemberian Izin Panas Bumi adalah merupakan wewenang pemerintah 
yang dalam hal ini diberikan oleh Menteri kepada Badan Usaha berdasarkan hasil penawaran kerja. Wewenang ini dijalankan oleh Menteri secara atribusi. Atribusi merupakan pemberian wewenang pemerintahan oleh pembuat undang-undang (legislatif) kepada suatu organ pemerintahan sebagaimana dijabarkan oleh H D Van Wijk dan Willem Konjnbelt (Ridwan HR, 2014). Dalam tataran praksis pemberian Izin Panas Bumi ini didelegasikan kepada Badan Koordinasi dan Penanaman Modal sebagaimana terdapat pada pasal 2 Peraturan Menteri Nomor 30 tentang Perubahan Kedua Atas Peraturan Menteri Energi dan Sumber Daya Mineral Nomor 35 Tahun 2014 tentang Pendelegasian Wewenang Pemberian Izin Usaha Ketenagalistrikan Dalam Rangka Pelaksanaan Pelayanan Terpadu Satu Pintu Kepada Kepala Badan Koordinasi Penanaman Modal menyatakan pemberian kewenangan izin usaha dibidang ketenagalistrikan baik pada penugasan Survei Pendahuluan dan Eksplorasi Panas Bumi dan Perizinan Berusaha dibidang panas bumi untuk pemanfaatan tidak langsung didelegasikan kepada Kepala Badan Koordinasi Penanaman Modal dan tidak memiliki hak substitusi atasnya.

Badan usaha mengajukan permohonan sebagai pemegang lelang Wilayah Kerja Panas Bumi (WK) atau badan usaha baru jika pemenang lelang adalah berdasarkan konsorsium yang telah ditentukan sebelumnya pada saat pembukaan lelang oleh Kementerian energi dan sumber daya mineral (KESDM) dengan mengajukan persyaratan surat penetapan pemenang lelang, akta pendirian berikut dengan akta perubahan terakhir badan usaha, Nomor Pokok Wajib Pajak (NPWP) badan usaha, surat keterangan domisili, tanda daftar perusahaan, daftar penerima manfaat, profil perusahaan dan bukti penempatan komitmen eksplorasi yang selanjutnya dilakukan verifikasi paling lama 5 (lima) hari kerja dan evaluasi dan selanjutnya dilakukan penyusunan rancangan keputusan kepala BKPM paling lama di 14 hari kerja, dan penerbitan perizinan berusaha dibidang panas bumi untuk pemanfaatan tidak langsung dapat dilakukan.

Dalam pengurusan panas bumi untuk pemanfaatan tidak langsung pada dasarnya berkorespondensi dengan organ pemerintahan lainnya seperti Kementerian Lingkungan Hidup dan Kehutanan (LHK) seperti adanya persetujuan lingkungan, Izin Pemanfaatan Jasa Lingkungan pada pengusahaan panas bumi dikawasan hutan lindung dll sehingga menciptakan 
relasi koordinatif antar kedua organ tersebut. Sama halnya dalam pengurusan panas bumi untuk pemanfaatan tidak langsung yang membutuhkan persetujuan lingkungan.

Merujuk mengenai legitimasi peraturan sebelum adanya persetujuan lingkungan yakni Peraturan Pemerintah Nomor 27 tahun 2012 tentang Izin Lingkungan (PP Izin Lingkungan) mengamanatkan pembangunan pembangkit listrik tenaga panas bumi sebagai salah satu usaha strategis nasional yang harus mendapatkan Izin Lingkungan dan kegiatan yang bersangkutan wajib mempunyai Upaya Pengelolaan Lingkungan - Upaya Pemantauan Lingkungan (UKL-UPL) dan/atau Analisis Mengenai Dampak Lingkungan (Amdal) yang meliputi eksplorasi panas bumi wajib UKL-UPL jika terletak didalam atau diluar area konservasi dan kegiatan eksploitasi wajib Amdal jika terletak didalam atau diluar area konservasi. Sekalipun dengan ditetapkannya Peraturan Pemerintah Nomor 22 tahun 2021 tentang Penyelenggaraan Perlindungan dan Pengelolaan Lingkungan Hidup (PP No 22 Tahun 2021) yang sekaligus mengeliminir pengusahaan panas bumi yang membutuhkan Izin Lingkungan, maka ketentuan ini mencabut ketentuan PP Izin Lingkungan tersebut. PP No 22 Tahun 2021 ini memiliki arah tujuan pengaturan dibidang panas bumi untuk pemanfaatan tidak langsung yang sama. Dalam arti mengamanatkan eksplorasi panas bumi yang tidak diikuti dengan usaha dan/atau kegiatan pendukung yang skala/besarannya wajib Amdal maka rencana usaha dan/atau kegiatan tersebut dapat dikecualikan dari pemenuhan Amdal. Sedangkan pada Tahapan esksplorasi sumber daya alam yang terbarukan wajib memiliki Amdal sebagaimana terdapat pada Pasal 5 ayat (1). Energi terbarukan tersebut merupakan energi yang berasal dari sumber energi terbarukan. Artinya pada tahapan eksplorasi panas bumi mempersyaratkan UKL-UPL sedangkan pada tahap eksplorasi menggunakan Amdal.

Menurut penulis pembedaan ini akan berdampak pada ketidakapastian oleh sebab penentuan wajib atau tidak adanya Amdal bergantung pada jenis kegiatannya bukan kepada penilaian instrumen perlindungan yang bergantung pada klasifikasi kegiatan berdasarkan potensi resiko dari setiap jenis kegiatannya. Hasil data yang diperoleh dari tahapan eksplorasi tersebut akan diserahkan kepada pemerintah dalam jangka waktu tiga tahun 
dan setiap setahun sekali terdapat mekanisme pelaporan online kepada Menteri. Persetujuan lingkungan wajib dimiliki oleh badan usaha sebagai penyelenggara panas bumi sebelum melakukan pengeboran sumur eksplorasi panas bumi dengan menggunakan UKL UPL dan persetujuan Lingkungan. Sedangkan pada tahap eksploitasi izin lingkungan wajib dimiliki oleh badan usaha sebelum melakukan eksploitasi dan pemanfaatan panas bumi.

Dalam pemrosesan persetujuan Lingkungan harus dilakukan secara simultan dan terintegrasi dengan studi kelayakan. Studi kelayakan merupakan kajian memperoleh informasi rinci mengenai aspek yang berkaitan dengan penentuan kelayakan ekonomis maupun teknis, dan lingkungan terhadap suatu rencana usaha dan/atau kegiatan pemanfaatan panas bumi yang diusulkan. Jangka waktu studi kelayakan ini bersamaan dengan jangka waktu eksplorasi yakni paling lama 5 (lima) tahun sejak Izin Panas Bumi dikeluarkan dan dapat diperpanjang 2 (dua) kali masing-masing 1 (satu) tahun. Artinya pengurusan persetujuan lingkungan untuk tahap eksploitasi dilaksanakan pada saat eksplorasi dan studi kelayakan dilakukan dan dapat diselenggarakannya kegiatan eksploitasi dan pemanfaatan panas bumi disesuaikan dan ditetapkan setelah penyampaian hasil studi kelayakan.

Permasalahan kemudian sebagai akibat pemberian perizinan berusaha dibidang panas bumi untuk pemanfaatan tidak langsung diberikan diawal setelah penetapan pemenang lelang dan bukan pada saat badan usaha menyelenggarakan untuk masing-masing kegiatan usahanya adalah semakin lemahnya penegakan hukum dibidang lingkungan hidup. Sebagaimana tergambar pada kasus kebocoran gas $\mathrm{H} 2 \mathrm{~s}$ (Hidrogen Sulfida) ketika berlangsung kegiatan pembukaan sumur (well discharge) pada sumur SM T02 pada proyek panas bumi unit II pada pukul 12.00 WIB yang terjadi pada PLTP Sorik Marapi yang dioperasikan oleh PT Sorik Marapi Geothermal Power (PT SMGP) di Mandailing Natal Sumatera Utara yang menyebabkan lima orang meninggal, empat puluh enam orang menjalani perawatan rumah sakit 3 (tiga) orang rawat jalan dan 1 (satu) orang mendapatkan perawatan medis. Secara teknis pembukaan sumur termasuk pada tahapan eksplorasi, akan tetapi secara normatif PT SMGP yang sudah memegang Izin Panas Bumi (sebagaimana akan disesuaikan menjadi perizinan berusaha dibidang panas bumi untuk pemanfaatan tidak langsung) sudah masuk ke tahap 
pemanfaatan. Maka idealnya suatu perizinan yang menjadi legalitas suatu pengusahaan dan mengacu pada pandangan Sjahran Basach bahwa izin sebagai alat pengendali, Izin Panas Buminya harus dicabut dengan urgensi keselamatan nyawa dan kerusakan dan/atau pencemaran lingkungan hidup.

Merujuk pada ketentuan Pasal 1 angka 36 UU PPLH menyatakan bahwa izin usaha dan/atau kegiatan adalah izin yang diterbitkan oleh instansi teknis untuk melakukan usaha dan/atau kegiatan. Izin usaha yang dimaksudkan disini juga dikategorikan merupakan Izin Panas Bumi. Maka dari itu ketentuan yang diatur dalam UU Panas Bumi tidak selaras dengan ketentuan UU PPLH. Artinya Izin Lingkungan (sebagaimana akan dilakukan penyesuaian dengan persetujuan lingkungan) harus didapatkan terlebih dahulu dan kemudian mendapatkan izin usaha (Izin Panas Bumi). Izin Usaha adalah izin yang diterbitkan oleh Lembaga OSS untuk dan atas nama Menteri, Pimpinan Lembaga, Gubernur atau Bupati/Walikota setelah pelaku usaha melakukan pendaftaran dan untuk memulai usaha dan/atau kegiatan sampai sebelum pelaksanaan komersial atau operasional dengan memenuhi persyaratan dan/atau komitmen sebagaimana terdapat pada Pasal 1 angka 8 Peraturan Pemerintah Nomor 24 Tahun 2018 tentang Pelayanan Perizinan Berusaha Terintegrasi Secara Elektronik yang dijelaskan pada bagan berikut:

Bagan 1 : alur pengurusan izin panas bumi/perizinan berusaha di bidang panas bumi

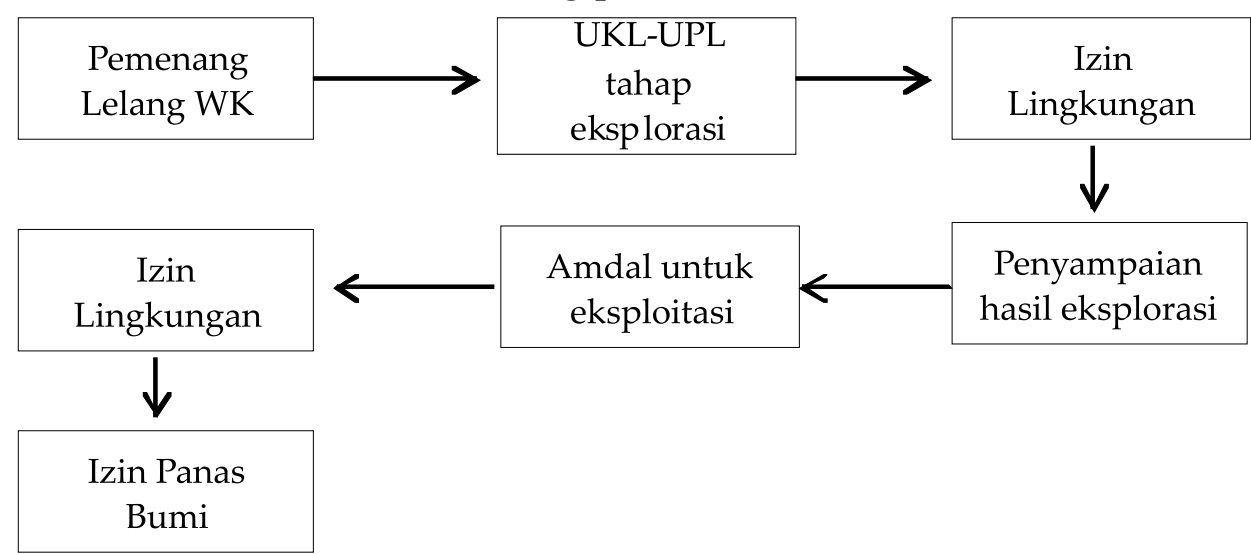

Urgensi izin sebagai alat pengendali ini semakin kuat seiring dengan dihapuskannya Pasal 36 Undang-undang Nomor 32 Tahun 2009 tentang 
Perlindungan dan Pengelolaan Lingkungan Hidup, bahwa "Setiap usaha dan/atau kegiatan yang wajib memiliki Amdal atau UKL-UPL wajib memiliki Izin Lingkungan". Melihat pada ketentuan norma ini menyatakan hal yang kontradiktif bahwa, Izin Panas Bumi dikeluarkan untuk keseluruhan tahapan penyelenggaraan panas bumi mulai dari eksplorasi, eksploitasi dan pemanfaatan tidak langsung. Berbeda dengan izin usaha pertambangan yang membagi klasifikasi penyelenggaraan perizinan menjadi Izin usaha pertambangan (IUP) eksplorasi, IUP khusus eksplorasi, IUP operasi produksi, IUPKhusus operasi, izin usaha pertambangan operasi produksi, dan izin usaha jasa pertambangan yang masing-masing diantaranya memiliki proses pengurusan perizinan yang berbeda dan membutuhkan izin usaha dan izin lingkungan sebagai pemenuhan persyaratannya dalam setiap bentuk kegiatannya.

Apabila mengacu pada pasal 40 ayat (1) UU PPLH menyatakan Izin Lingkungan merupakan persyaratan memperleh izin usaha dan/atau kegiatan dan ketiadaan Izin Lingkungan akan dikenakan pidana. Apabila mengacu pada UU Panas Bumi tidak mensyaratkan adanya Izin Lingkungan sebelum Izin Panas Bumi namun Izin Lingkungan hanya diperlukan pada setiap kegiatan seperti eksplorasi dan eksploitasi. Penjelasan pasal 40 ayat (1) izin usaha dan/atau kegatan dalam ayat ini termasuk izin yang disebut dengan nama izin operasi dan izin konstruksi. Ketiadaan Izin Lingkungan ini tidak berimplikasi pada dicabutnya atau dibatalkannya izin usaha (Izin Panas Bumi) namun lebih kepada pelarangan kegiatan. Oleh sebab pada dasarnya terdapat koherensi antara Izin Lingkungan dan Izin Panas Bumi yang saling mempengaruhi secara simultan. Dengan itu kasus di PT SGMP tersebut terhadap Izin Panas Buminya tidak akan dicabut. Sebagai langkah mitigasi risiko lanjutan Kemen ESDM akhirnya memutuskan menghentikan sementara proses produksi. Sekalipun begitu eksternalitas biaya lingkungan dan keselamatan masyarakat tidak sebanding dengan eksternalitas perusahaan. Inilah yang menjadi fundamen bahwa keselamatan masyarakat dan perlindungan lingkungan hidup menjadi penting dalam penyelenggaraan kegiatan/usaha yang berkaitan dengan lingkungan.

Izin lingkungan tersebut dikeluarkan oleh Menteri, gubernur, walikota/ bupati. Dalam kasus diatas izin lingkungan PT SGMP didapatan dari 
Menteri karena secara atribusi kewenangan ini didapatkan dalam UUPPLH. Idealnya dalam suatu konstruksi integrasi izin, maka apabila satu izin itu tidak memenuhi persyaratan dan/atau dalam penetapan izin dalam suatu keputusan ternyata dalam perkembangannya menimbulkan kerugian maka terhadap izin fundamennya harus dicabut agar kegiatan dan/atau usahanya tidak dijalankan. Akan tetapi di Indonesia belum terselenggarakan demikian, sehingga dengan adanya kerugian terhadap masyrakat dan lingkungan diatas izin panas buminya tidak dicabut begitupun dengan izin lingkungannya pada tahapan pemanfaatan.

Sebagai komparasi di daerah Jawa Barat terdapat pengembangan Panas Bumi yang tidak dilanjutkan operasionalnya dengan sebab yang simpang siur sejak bulan Desember 2014 tepatnya di kaki Gunung Tangkuban Perahu Desa Karyawangi, Kecamatan Parongpong, Kabupaten Bandung Barat. Padahal dilokasi tersebut pada awalnya sudah diangkut tiga unit tangki lumpur, satu unit genset rig, satu unit tangki air, cementing unit, enam unit portakem, empat unit gudang material dan satu unit genset cab untuk mendukung proses eksplorasi namun kini hanya menyisakan lahan kosong dengan lubang bekas pengeboran dengan luas $0,5 \mathrm{ha}$. Hingga saat ini beberapa alat-alat berat masih berada disekitar lokasi dan dijaga oleh petugas keamaanan perusahaan dan beberapa kapling gudang sebagaimana disampaikan oleh Maman yang merupakan salah satu warga di Desa Kolonel Masturi Nomor 299 Kabupaten Bandung Barat yang berada di sekitar wilayah kerja rencana panas bumi.

Kondisi ini menjadi catatan buruk bagi pengusahaan panas bumi untuk pemanfaatan tidak langsung di Indonesia karena WKP dibiarkan begitu saja padahal UU Panas Bumi Pasal 30 ayat (1) mengamanatkan agar tahap eksplorasi diselesaikan dalam jangka waktu paling lama lima tahun sejak Izin Panas Bumi diterbitkan dan dapat diperpanjang dua kali masing-masing satu tahun. Hal ini sekaligus menunjukan bahwa pemerintah dalam mengeluarkan Izin Panas Bumi harus menerapkan prinsip kehati-hatian sehingga potensi kerusakan lingkungan dapat diminamilisir. Dalam kegagalan eksplorasi di Desa Karyawangi tersebut lobang bekas pengeboran sumur tidak bisa dilakukan pemulihan dengan penimbunan oleh pemerintah daerah seperti administrator Kebun Sukawana PTPN VIII karena wilayah WKP tersebut sudah menjadi otoritas PT Indonesia Power dengan PT Tangkuban Perahu 
Geothermal Power sebagai subskontraktor.

PT Indonesia Power memiliki hak sewa atas tanah yang berada di tanah PTPN Nusantara 8 hingga 10 (sepuluh) tahun terhitung sejak tahun 2014 yang lalu sehingga akan berakhir pada tahun 2024 mendatang. Menurut informasi yang sama dari Maman menyatakan bahwa pada tahun 2016 sudah dilakukan mobilisasi barang-barang dan alat-alat beat dan berhenti operasi pada tahun 2018 tepatnya di bulan Desember. Salah satu hal yang dicermati oleh penulis adalah tidak adanya koordinasi antara pemerintah pusat, pemerintah daerah dan badan usaha terkait upaya pelaksaanaan kegiatan ini. Hal ini disebabkan dengan adanya informasi yang ambigu dan simpang siur terkait pertimbangan penghentian survei pendahuluan dan eksplorasi yang dilakukan. Semisalnya saja menurut Oneng Supriyatna selaku Sekretaris Desa Sukawana, Kecamatan Parongpong Kabupaten Bandung Barat yang menyatakan bahwa unit pemerintahan Desa karyawangi tidak mengetahui secara pasti mengenai rencana survei pendahuluan dan eksplorasi yang dilakukan dan mengetahui kabar tersebut pada saat sudah ada mobilisasi barang dan alat berat.

Hal yang sama disampaikan oleh Haryono yang merupakan kepala Rukun Warga 13 Desa Sukawana yang menyatakan bahwa tidak adanya informasi apapun yang disampaikan oleh badan usaha baik kepada dirinya maupun kepada warga sekitar sehingga dalam setiap tindakan yang dilakukan oleh badan usaha tidak melibatkan partisipasi daripada masyarakat. Kewajiban badan usaha untuk mengadakan sosialisasi bersama masyarakat sekitar terlebih lagi untuk meninjeksikan air badan usaha tersebut menggunakan sumber air permukaan yang berasal dari sungai Luwilayung yang pada dasarnya merupakan domain publik. Menurut Suparto Wijoyo dalam suatu pengambilan keputusan yang berkaitan dengan pengelolaan lingkungan hidup termasuk aspek perizinan harus mengacu pada prinsip prosedur perizinan lingungan berbasis good environmental governance seperti menekankan adanya openbaarheid van bestuur atau keterbukaan dengan adanya kontribusi dan partisipasi masyarakat seperti adanya akses informasi perizinan secara terpadu hingga keputusan dikeluarkan (Suparto Wijoyo, 1999).

Hal ini sejalan dengan principle 10 Rio Declaration yang menyatakan 
bahwa isu berkaitan dengan lingkungan seharusnya mengikutsertakan pihak dan masyarakat yang terkait pada tingkatan yang relevan. Negara yang diaktualisasikan dalam tindakan pemerintah harus meningkatkan kesadaran serta partisipasi umum dengan memberikan informasi yang luas, efektif secara peradilan dan adminsitrasi. Diana Conyers, alasan partisipasi masyarkaat penting diantaranya partisipasi merupakan alat atau sarana dalam mendapatkan informasi tentang kondisi, sikap, kebutuhan dan masyarakat pembangunan akan lebih memiliki legitimasi karena masyarakat merasa dilibatkan dari proses persiapan, pelaksanaan maupun lainnya, mendorong partisipasi umum berkembang sebab adanya anggapan suatu hak demokrasi berjalan apabila masyarakat dilibatkan dalam proses pembangunan terhadap masyarkat itu sendiri (Diana Conyers, 1992). Maka dari itu menjadi penting pelibatan masyarakat sekitar terhadap rencana pengembangan panas bumi di WK tersebut.

Mengenai alasan dan pertimbangan penghentian proses survei pendahuluan dan eksplorasi dikarenakan pada saat survei landaian suhu mengalami kendala di sekitar 600 meter padahal pipanya harus mengenai batuan rekahan atau cap rock dengan kedalaman 1.500 meter. Maka dari itu untuk sekarang well pad tersebut ditutup. Berdasarkan informasi yang didapatkan dari salah satu pekerja menyatakan bahwa nantinya rencana pengembangan panas bumi ini akan dilanjutkan namun untuk rinciannya belum didapatkan informasi lebih lanjut. Informasi ini didapatkan dari Yanto yang merupakan petugas keamanan perusahaan PT Indonesia Power. Maka dari itu hubungan pusat dan daerah dihadapkan pada kondisi tidak proporsionalitasnya pembagian urusan pemerintah pusat dengan pemerintah daerah dalam konteks pengembangan energi panas bumi dan terbatasnya kewenangan pemerintah daerah dalam urusan panas bumi sehingga dalam upaya optimalisasi pengembangan panas bumi maka perlu dilakukannya perubahan terhadap peraturan perundang-undangan panas bumi dan pengaturan Pemerintah daerah dalam acara webinar Pusat Studi Hukum Energi dan Pertambangan oleh Bisman Bhaktiar pada 17 Desember 2020).

Izin panas bumi yang telah didapatkan oleh PT Indonesia Power hingga saat belum dicabut/dikembalikan kepada Menteri sehingga menunjukan tendensi perizinan yang tidak berkepastian. Padahal dengan gagalnya survei 
pendahuluan dan eksplorasi Izin panas bumi sebagai izin usaha harus dievaluasi terlebih dahulu dan izin lingkungannya harus ditinjau ulang pemrosesannya sebab melibatkan multisektor pemberi izin dalam rencana pengembangan panas bumi ini.

Secara konsep sistem Perizinan di Indonesia cenderung fragmented scheme sehingga perizinan berdiri sebagai entitas yang terpisah dan seolah tidak berkaitan dengan izin lainnya atau bersifat sektoral. Padahal pada dasarnya izin merupakan wujud kehendak mengendalikan suatu aktifitas, mencegah bahaya lingkungan, melindungi obyek tertentu, membagi benda-benda yang jumlahnya sedikit, mengarahkan dan menyeleksi aktifitas perizinan berdasarkan draken horecawet (Tatiek Sri Djamiati, 2004). Selain itu menurut Brian dan Khaterine Thomson izin adalah pengawasan dari pemerintah terhadap aktifitas tertentu. Maka dari itu dapat tergambarkan realitas izin adalah norma pengatur tingkah perbuatan masyarakat dan kemudian disebut preventieve instrumentent untuk mencegah dan mengedalikan perbuatan melanggar masyarakat terhadap suatu ketentuan tertentu. Adanya inrelativitas antara Izin Lingkungan dan Izin Panas Bumi mengharuskan Indonesia memiliki sistem integrale mileuvergunning terpadu, terintegrasi dan konsisten.

Menurut pendapat Verschuuren, pada dasarnya subyek hukum hanya membutuhkan satu izin untuk suatu kegiatan dan/atau usaha sekalipun kegiatanusaha tersebut diatur dalam Undang-Undangyang berbeda (Jonathan Verschuuren, 2004) sehingga aspek perizinannya bukan hanya ditujukan dalam lingkup kegiaan usaha yang berdampak terhadap lingkungan secara fisik namun juga menyangkut pemanfaatan lahan, pembangunan, perubahan tata ruang untuk mendirikan (infrastruktur) PLTP (Hanna Durtge Tolsma, 2014). Terdapat dua skema perizinan panas bumi yang dapat dilakukan, pertama melakukan integrasi eksternal izin panas bumi dengan mekanisme perizinan berusaha dibidang panas bumi untuk pemanfaatan tidak langsung dibagi berdasarkan klasifikasi kegiatannya (ekplorasi, ekspolitasi, dan pemanfaatan tidak langsung) yang masing-masing kegiatannya tersebut harus mendapatkan izin lingkungan. Apabila izin lingkungannya tidak dipenuhi maka menjadi batal izin panas buminya. Skema kedua adalah dengan melakukan integrasi eksternal dengan cara izin panas bumi yang 
mana izin lingkungan merupakan subordinat izin panas bumi sehingga apabila izin lingkungan tidak dipenuhi maka izin panas bumi tidak dapat diberikan dan kewenangan pemberian izin panas bumi berada pada satu izin saja yakni izin panas bumi yang berada di menteri ESDM. Praktek seperti ini lazim dilakukan di negara Belanda yang memiliki sistem hukum relatif mirip dengan Indonesia dengan skema izin APPA yang memungkinkan diajukannya satu aplikasi untuk satu izin kepada satu badan pemerintah, yang kemudian akan diproses berdasarkan satu prosedur dan satu keputusan (A.B Blomberg, A.A.J De Gier dan J Robbe, 2009) sehingga lebih efisien.

Hukum merupakan norma sosial yang tidak terlepas dari nilai yang ada dimasyarakat dan hukum itu sendiri merupakan konkretisasi nilai-nilai yang ada pada suatu masyarakat dan pada suatu saat (Soerjono Soekanto, 1999). Pemerintah atas nama negara dapat melakukan penguasaan, pengaturan dan pengelolaan panas bumi yang koheren dengan amanat Undang Undang Dasar Negara Republik Indonesia Tahun 1945 Pasal 33 yang menyatakan, "bumi, air dan kekayaan alam yang terkandung didalamnya dikuasai oleh negara dan dipergunakan untuk sebesar-besarnya kemakmuran rakyat". Untuk "sebesar-besarnya kemakmuran rakyat" menjadi tujuan daripada pengelolaan kekayaan alam oleh negara dan hak penguasaannya adalah pada negara (Adrian Sutedi, 2012). Norma ini kemudian dikonkretkan dalam UU No 30 tahun 2007 tentang energi, UU No 21 tahun 2014 tentang panas bumi jo UU No 11 Tahun 2020 tentang Cipta Kerja, UU No 10 tahun 1997 tentang ketenagalistrikan UU No 11 Tahun 2020 tentang Cipta Kerja, UU No 41 tahun 1999 jo. UU No 9 tahun 2004 tentang kehutanan UU No 11 Tahun 2020 tentang Cipta Kerja, UU No 5 tahun 1990 tentang konservasi SDA hayati dan ekosistemnya, UU No 32 tahun 2014 tentang Kelautan dan UU No 27 jo. UU No 1 tahun 2014 tentang pengelolaan wilayah pesisir dan pulau-pulau kecil.

Mengenai hak menguasai negara akan selalu tercermin dalam konstruksi politik hukum suatu negara. Menurut Teuku Mohammad Radhi Politik hukum diartikan sebagai pernyataan kehendak penguasa negara mengenai hukum yang berlaku di wilayahnya dan arah perkembangan hukum yang dibangun (Teuku Muhammad Radhi, 1973) sehingga pendapat ini berkaitan dengan ius constituendum dan ius constitutum. Pendapat lain disampaikan oleh Abdul Hakim Garuda Nusantara yang menyatakan bahwa politik 
hukum nasional meliputi pelaksanaan ketentuan perundang-undangan dan hukum yang sudah ada secara konsisten; adanya pembangunan hukum yang pada dasarnya merupakan pembaharuan hukum terhadap ketentuan hukum yang sudah ada sehingga ketentuan yang sudah dianggap tidak relevann diperlukan pembentukan ketentuan hukum baru untuk memenuhi perkembangan yang ada di masyarakat; adanya penegasan fungsi lembaga pelaksana hukm berikut pembinaan anggoanya; terdapat upaya peningkatan kesadaran hukum masyarakat berdasarkan persepsi penguasa pengambil kebijakan (Abdul Hakim Garuda Nusantara, 1985). Pengambilan persepsi ini diartikan secara harafiah bahwa politik hukum adalah merupakan kebijakan hukum atau legal policy yang akan diterapkan oleh suatu pemerintah.

Hal ini didasarkan pada aspek teritori berlakunya politik hukum; adanya proses pembaharuan dan pengembangan hukum yang berdimensi ius constitutum dan menciptakan sudut ius constituendum serta menitikberatkan pada peran dan fungsi lembaga dan pembinaan para aparat penegak hukum. Maka dari dua pandangan tersebut dapat dikonklusikan bahwa politik hukum merupakan suatu kebijakan dasar penyelenggara negara dibidang hukum yang sedang, telah berlaku dan akan berlaku dan bersumber dari nilai yang berlaku di masyarakat dalam pencapaian tujuan negara (Imam Syaukani dan A Ahsin Thohari, 2005). Konsep hak menguasai negara akan melekat pada kewajiban dan tanggungjawab negara, sebagaimana disampaikan oleh Jul Fajri, kewajiban negara tentang sesuatu maupun menerima pembebanan yang merupakan akibat atas tindakan yang dilakukan oleh pemerintah sendiri maupun pihak lain. Adapun dimensinya diantaranya menerima kesalahan yang dilakukan; memberikan ganti kerugian atau dengan melakukan perbuatan pemulihan sebagaimana keadaan semula sehingga inilah yang kemudian menentukan besar kecil tanggungjawab negara (Jazim Hamidi, 2009).

Secara epistimologi konsep tanggungjawab negara ini berangkat dari etimologi liability atau responsibility yang berarti the state of being answerable for an obligation and includes judgement, skill, ability, and capacity. The obligation to answer for an act done, and to repair or otherwise make restitution for any injury it may have caused (Henry Campbell Black, 1990). Sedangkan liability diartikan sebagai all character of debts and obligations; an obligation one bound in law or 
justice to perform; any kind of debt or liability, either absolute or contingent, express or implied condition of being actually or potentially subject to an obligation; condition of being responsible for a possible or actual loss, penalty, evil, expense or burden; condition which creates a duty to perform an act immediately or in the future. Maka dari itu dapat dikonklusikan bahwa memberikan suatu keputusan tentang izin untuk melakukan suatu usaha dan/atau kegiatan harus berdasarkan kepada tanggungjawab negara sebagai pemegang kuasa penguasaan negara.

Intervensi dominan pemerintah dalam usaha dan/atau kegiatan dibidang panas bumi adalah ada tahapan perizinannya sebagai prior approval. Dalam konstruksi hukum administrasi negara, persetujuan pemerintah dituangkan dalam bentuk izin, lisensi maupun sertifikasi (Alexandre Kiss dan Dinah Shelton, 1997). Selain itu juga terdapat persetujuan lain dalam bentuk konsesi dan dispensasi (Prajudi Atmosudirdjo, 1981) serta persetujuan tertulis dari pemerintah yang berwenang dapat dianggap sebagai suatu izin sebagaimana terjadi dalam perkara Republik Indonesia dengan PT Newmont Minahasa Raya dan Ricard Bruce Ness pada tahun 2005 yang dalam pertimbangan putusannya menyatakan bahwa persetujuan Menteri LHK menyerahkan persetujuan tertulis kepada perusahaan untuk melakukan pembuangan limbah ke laut merupakan bentuk izin pula. Hal ini kemudian menjadikan instrumen perizinan semakin bergeser pada suatu keputusan pejabat pemerintahan mengenai suatu hal tanpa memenuhi syarat sebagaimana ditentukan yang kemudian menjadi preseden dalam perkara berikutnya.

Dalam ketentuan Undang-Undang Nomor 11 Tahun 2020 tentang Cipta Kerja (UU Ciptaker) mengklasifikasikan bentuk perizinan berbasis pada risiko dengan penilaian gradual atau tingkat bahaya dan potensi terjadinya bahaya dengan skala kegiatan usaha berisiko rendah; kegiatan usaha berisiko menengah (berisiko menengah rendah atau risiko menengah tinggi), atau kegiatan usaha berisiko tinggi sebagaimana terdapat pada Pasal 7 ayat (7) Bab III Peningkatan Ekosistem Investasi dan Kegiatan Berusaha UU Cipta Kerja.

Usaha tingkat risiko rendah dalam bentuk Nomor Induk Berusaha sebagai legalitas dan Tipe pengawasan I, tingkat risiko menengah rendah dalam bentuk sertifikat standar dengan tipe pengawasan 2, risiko menengah tinggi dalam bentuk sertifikat standar dengan tipe pengawasan 3 dan risiko tinggi dalam bentuk Izin dengan tipe pengawasan 4. Maka dari itu penilaian 
dilakukan dengan Risk Based Approach (RBA) dengan prinsip Trust but Verify. Pengaturan berusaha ini diperkenalkan dengan menekankan adanya penyelenggarakan pengawasan dan tidak pada instrumen perizinan. Padahal izin merupakan suatu bentuk pengendalian pemerintah secara yuridispreventif terhadap suatu kegiatan dan/atau usaha yang dilakukan. Izin difungsikan sebagai legal base; instrumen untuk menjamin kepastian hukum; untuk melindungi kepentingan dan alat bukti dalam hal mengklaim sesuatu.

Apabila kemudian terdapat dugaan pelanggaran administrasi maupun pidana maka izin yang telah diberikan dapat dicabut/dibatalkan sehingga kegiatan dan/usaha berpotensi merusak dan/atau mencemarkan lingkungan hidup dapat diminimalisir. Artinya prinsip atur dan awasi atau command and control tidak benar-benar dijalankan oleh pemerintah. Pemerintah nantinya melalui Peraturan Pemerintah akan menetapkan standarisasi baku serta kewajiban mengenai kriteria usaha dan/atau kegiatan yang diklasifikasikan berdasarkan analisis risiko dalam UU Ciptaker dan pada dasarnya aturan ini dirancang disertai dengan adanya sanksi dari atas pelanggaran terhadap standarisasi dan kewajiban tersebut (Michael A Heldeweg dan Rene J G H Seerden, 2012).

Kemudian jika merujuk dalam UU Ciptaker justru ancaman sanksi pidana terhadap badan usaha yang melakukan pelanggaran hukum terhadap pelaksanaan kegiatan panas bumi pemanfaatan tidak langsung justru dihilangkan. Dalam struktur hukum Indonesia memosisikan sanksi pidana harus diatur dan dipaksakan dalam ketentuan Undang-Undang atau Peraturan Daerah, namun akan menimbulkan konsekuensi logis berbeda apabila ancaman sanksi pidana dimasukan dalam standarisasi baku risiko dan kewajiban pemerintah terhadap badan usaha apalagi jika ancaman pidana tersebut tidak dimasukan sama sekali sehingga badan usaha hanya dikenakan sanksi administratif sebagaimana terdapat pada Pasal 26 ayat (2), pasal 27 ayat (1) dan ayat (3), pasal 31 ayat (3) dan/atau pasal 32 ayat (2) UU Pabum. Langkah krusial dalam UU Ciptaker ini pada dasarnya merupakan bentuk reformasi administrasi dengan jalur mereformasi di bidang hukum dengan upaya sinkronisasi maupun menghapus peraturan kompelks melalui penelaahan regulasi yang detail. Regulasi ini kemudian menyerderhanakan ketentuan panas bumi, ketenagalistrikan dll (Damanik). 
Dalam perizinan ini kemudian diklasifikasikan berdasarkan bentuk pengawasan berupa izin atau hanya notifikasi saja. Untuk klasifikasi tingkat risiko rendah, risiko menengah rendah dan risiko menegah tinggi dapat menggunakan prosedur notifikasi kepada pemerintah sehingga proses dan hasil suatu pengorganisasian usaha dan/atau kegiatan dilaporkan kepada pemerintah sehingga tidak menjadi alasan bagian kegiatan dengan risiko ini tidak memberikan laporan notifikasi kepada pemerintah secara berkala. Sedangkan untuk risiko tinggi menggunakan izin. Pendekatan ini relatif mirip sebagaimana diterapkan di Belanda bahwa untuk masing-masing kegiatan dan/atau usaha dibagi berdasarkan beberapa tipe yakni tipe A untuk kegiatan dan/atau usaha yang berdampak kecil artinya tidak begitu signifikan terhadap lingkungan sehingga tidak harus melakukan pelaporan kepada pejabat pemerintahan yang berwenang dan tidak wajib mempunyai izin APPA. APPA Adalah Singakatan Dari All-In One Permit For Physical Aspects yaitu suatu prosedur perizinan yang mengintegrasikan beberapa izin, Laporan Kepada Pemerintah (A.B Blomberg, A.A.J.De. Gier, dan J Robbe, 2009).

Kedua adalah kegiatan dan/atau usaha Tipe B yang harus memberikan pelaporan atau notifikasi kepada pemerintah dan dalam keadaan tertentu diwajibkan memiliki izin APPA dan ketiga adalah klasifikasi kegiatan dan/atau usaa dengan Tipe $\mathrm{C}$ yang mempunyai dampak luas terhadap lingkungan dan harus memenuhi IPPC Directive. IPPC Merupakan Singkatan Dari Integrated Pollution Prevention And Control Yang Dilegitimasi Berdasrkan Directive Nomor 96/61/EC Yang Menyatakan Setiap baku mutu, emisi, standarisasi, parameter maupun langkah teknis harus dijalankan berdasarkan Best Available Techniques (BAT) Dengan Memperhatikan Kondisi Geografis, Lingkungan Dan Instalasi Beserta Aspek Teknis Lainnya. Sebagaimana Dijelaskan Pada Art 1 Angka 12 Bahwa BAT Merupakan The Most Effective And Advanced Stage In The Development Of Activities And Their Methods Of Operation ... To Reduce Emissions And The Impact On The Environment .. . Maka pemerintah Belanda akan mengeluarkan satu keputusan izin dengan satu pengajuan permohonan izin, artinya masih dilakukan oleh pihak Kementerian. Konsep ini secara gradual memberikan penelaahan bahwa harus dilakukannya integrasi izin panas bumi di Indonesia. 
Beda halnya dengan Australia yang memiliki satu badan khusus dalam memberikan izin maupun persetujuan yakni Environment Protection Authority yang tidak tunduk pada suatu kementerian tertentu. EPA bertugas untuk mengeluarkan licensing guidlines yang menelaah tingkat resiko dan rekomendasi penggunaan izinnya dengan menerapkan standard conditions yang mesti dipenuhi oleh pemegang izin seperti adanya laporan tahunan dari pemegang izin jika terdapat kondisi yang mencemarkan/merusak maupun potensinya terhadap lingkungan hidup. Terdapat dua kondisi yang menentukan keputusan izin atau persetujuan yakni kewajiban untuk memenuhi standard conditions dan dilaksanakan assessment lanjutan terkait risiko terhadap lingkungan. Mengenai ruang lingkup dan metode yang diperhatikan oleh EPA adalah pada lingkup to identify concerns and issues requiring consideration; to facilitate an efficient environmental Impact (EIS) preparation process; To enable those responsible for EIA to properly brief the study team on the alternatives and impacts to be considered at different depths of analysis; To provide an opportunity for public involvement dan To save time.

Tomlinson menyatakan ini berdasarkan ANZECC's tahun 1996 tentang guidelines and criteria for determining the need for and level of environmental impact assessment in Australia bahwa, panduan tersebut sebagai pengingat kepada seseorang tentang multi element yang harus diperhatikan dan memiliki dampak terhadap lingkungan suatu saat nanti (Ian Thomas, 2010). mengingat bahwa EIA dikeluarkan sebagai upaya identifikasi, prediksi, evaluasi dan mitigas terhadap lingkungan dan dampak lain yang berasosiasi dengan perkembangan politik, rencana dan program. Hal serupa juga disampaikan oleh IAIA (International Association For Impact Assessment) yang menekankan adanya assessment dalam setiap jenis kegiatan dan/atau usaha yang berhubungan dengan lingkungan hidup sebagaimana terdapat dalam buku Principles Of Environmental Impact Assessment.

Berefleksi terhadap konstelasi Indonesia mengenai izin panas bumi atau yang disebut perizinan berusaha panas bumi dalam UU Ciptaker membawa perubahan struktural terhadap pengembangan panas bumi. Sebab dalam UU Ciptaker Izin Lingkungan dihapus dan diganti dengan Persetujuan Lingkungan sebagaimana terdapat dalam Pasal 13 huruf b. Maka dari itu dalam kegiatan panas bumi eksplorasi, eksploitasi dan pemanfaatan tidak 
langsung, tidak lagi membutuhkan izin lingkungan. Jika merujuk ke Belanda maka pemanfaatan tidak langsung panas bumi berada pada bidang Tipe B yang berimplikasi pada kewajiban badan usaha untuk sekadar melakukan pelaporan kepada pemerintah. Sedangkan dalam perubahan UU Ciptaker maka panas bumi dapat dikategorikan sebagai risiko menengah tinggi dalam bentuk sertifikat standar dengan tipe pengawasan 3 sebab dalam UU Panas bumi tidak lagi mengklasifikasikan panas bumi menjadi usaha pertambangan dan dilain sisi dalam UU Ciptaker juga menyatakan secara eksplisit bahwa panas bumi merupakan rencana strategis nasional dan menjadi prioritas pembangunan. Kemudian yang menjadi kekhawatiran penulis adalah potensi terjadinya pencemaran dan/atau kerusakan lingkungan hidup sebagai akibat kegiatan panas bumi seperti blow out seperti yang terjadi di dataran Alasehir di Turki, terjadinya amblesan yaitu penurunan permukaan tanah karena ekstraksi fluida di kedalaman yang relatif dangkal sehingga injeksi fluida kedalam batuan yang tidak maksimal maka ekstraksi tersebut menyebabkan menurunnya tekanan yang ada diformasi batuan sekitar 25 bar seperti yan terjadi di Selandia Baru tepatnya pembangkit energi geothermal Wairakei tahun 1958.

Ancaman degradasi lingkungan nyata dari PLTP adalah berupa geothermal brine dan sludge yang mengandung silika, kalium, magnesium yang apabila dibuang begitu saja dapat membahayakan kesehatan manusia dan makhluk hidup lainnya serta lingkungan hidup (Wahyu Mei Trianto, 2019). Aspek keekonomiannya justru akan lebih besar dengan adanya ancaman terhadap lingkungan tersebut atau eksternalitas. Eksternalitas terjadi apabila keputusan yang diambil akan mempengaruhi keadaan orang lain secara langsung maka pengambil keputusan akan menanggung privat costs dan biaya eksternalisasi lain yang ditanggung secara social costs yang tercermin pada marginal costs of private production dan marginal social external costs (Robert S Pindyck dan Daniel L Rubindeld, 2001) bahwa masyarakat mendapatkan dampak yang tidak sebanding dengan pencemaran dan terganggunya kesehatan. Untuk menjamin kontinuitas pengusahaan maka pada tahap pemberian persetujuan lingkungan pada setiap klasifikasi pengusahaan panas bumi maka perlu diberlakukan komitmen eksplorasi kepada badan usaha. Komitmen eksplorasi merupakan dana jaminan 
pelaksanaan pengeboran sumur eksplorasi yang dibagi menjadi US\$ AS 10 juta untuk kapasitas PLTP lebih dari atau sama dengan 10 megawaat atau US\$ 5 Juta Untuk Kapasitas Kurang Dari 10 Megawatt kemudian disetorkan kepada bank berstatus BUMN Pasal 40 Peraturan Pemerintah Nomor 7 Tahun 2017 tentang Panas Bumi untuk Pemanfaatan Tidak Langsung.

Pertimbangan komitmen berada di tahap eksplorasi dikarenakan resiko ekslorasi yang mencapai 90 persen maka harus dilakukan antisipasi dan mitigasi dalam assessment yang nantinya akan dilakukan. Apabila bahan berbahaya tersebut realitanya merusak/mencemarkan lingkungan maka pemerintah tidak dapat mencabut izin berusaha panas buminya dan proses preventif-mitigasinya akan cenderung lama sebab izin ini dikeluarkan lebih dahulu dibandingkan dengan persetujuan lingkungan. Maka dari itu untuk menyinkronkan regulasi dan standar baku yang nantinya akan diaktualisasikan dalam Peraturan Pemerintah maka perlu dibentuk suatu badan khusus untuk memberikan assessment sehubungan dengan pengusahaan panas bumi yang independen dan tidak tunduk pada kementerian sebagaimana diterapkan di Australia.

Hal ini ditujukan agar tidak adanya upaya bargaining power oleh badan usaha terhadap pemerintah sebab posisi hirarkis pemerintah sebagai prior approval perizinan sudah dihilangkan pada izin lingkungan menjadi persetujuan lingkungan. Mekanisme ini merupakan bentuk penegakan hukum lingkungan yang merupakan suatu rangkaian tahapan atau proses terakhir dalam rangkaian regulatory chain yang meliputi: legislation, regulation, issueing permits, implementation dan enforcement (G H Addink, 2002), maka dari itu proses pengusahaan panas bumi harus dipandang secara gradual sebagai satu kesatuan yang tidak terpisahkan termasuk instrumen yang melegitimasi setiap kegiatan dan/atau usaha sehingga dengan senyatanya menempatkan negara dengan hak menguasai negaranya dan tanggungjawab negara memberikan perlindungan dan kepastian hukum yang berkeadilan pada setiap pihak berkepentingan termasuk masyarakat.

Sebagaimana disampaikan oleh Bagir Manan bahwa pengawasan terhadap lingkungan harus dibedakan pengawasan negatif represif yakni setelah tindakan dilakukan dan pengawasan negatif preventif dan pengawasan positif yaitu pemerintah yang lebih tinggi memulihkan kelalaian 
pemerintah yang lebih rendah (Bagir Manan, 1994). Sedang menurut J.B.J.M. Ten Berg pengawasan dalam hukum administrasi harus berlandaskan kepada legitimasi, instrumen hukum administrasi, norma hukum administrasi dan kumulasi sanksi yang pada hakikatnya tercermin pada pemberian izin berusaha panas bumi/izin panas bumi sehingga memosisikan pengawasan sudah dilakukan pada tahap pemberian izin.

\section{Simpulan}

Pada dasarnya pengembangan energi panas bumi untuk pemanfaatan tidak langsung harus dilakukan seiring dengan rencana transisi dan diversifikasi energi dalam kebijakan energi nasional. Hal ini berkorelasi dengan upaya meminimalisir kerusakan dan/atau pencemaran lingkungan hidup dengan menyesuaikan potensi kewilayahan Indonesia yang berada pada tumbukan lempengan tektonik sehingga terdapat jalur gunung api didaerah pasifik (pacific ring of fire). Akan tetapi hambatan regulasi, birokrasi yang cenderung rumit justru menghambat terselenggaranya progresifitas pengembangan panas bumi yang menimbulkan ketidakpastian. Isu tumpang tindih dan dispartitas kewenangan badan penyelenggara perizinan panas bumi untuk pemanfaatan tidak langsung menghambat birokrasi. Disisi lain perubahan paradigma adanya persetujuan lingkungan berbasi risiko terhadap kegiatan dan/atau usaha sebagaimana diatur dalam ketentuan UU Cipta Kerja menyebabkan hadirnya tantangan baru terhadap izin berusaha panas bumi seperti dengan adanya klasifikasi tipe izin berdasarkan analisis risiko, penghapusan izin lingkungan yang berkorespondensi dengan perizinan berusaha panas bumi. Maka dari itu perlu dilakukannya integrasi perizinan dalam rangka perizinan yang salah satunya merujuk pada negara Belanda. Selain itu penulis berharap bahwa pemerintah dapat membentuk suatu badan khusus yang mengatur dan menetapkan standar baku terhadap usaha dan/atau kegiatan dan menggolong-kannya pada klasifikasi perizinan sebagaimana sistem assessment yang diterapkan di Australia oleh EPA. Dengan demikian kondisi tumpang tindih kewenangan intra pemerintah pusat, pemerintah daerah dan kepentingan perlindungan lingkungan dapat berjalan secara efisien melalui integrasi izin. 


\section{Daftar Rujukan}

Addink, G. H. (2002). Environmental Law In A Comparative Perspective National, European And International Law. Literaturem Institute Of Constitutional And Administrative Law Utrecht University .

Adisapoetro, W. F. (1987). Pengantar Ilmu Hukum Administrasi Negara. Jakarta: Pradnya Paramita.

Assessment, I. A. Principles Of Environmental Impact Assessment. United Kingdom: United States And Loncoln Press.

Atmosudirdjo, P. (1981). Hukum Administrasi Negara. Jakarta: Ghalia Indonesia. Bhaktiar, B. (2020). Pengembangan Energi Baru Terbarukan Dan Konservasi Energi Dengan Penguatan Daerah. (Hal. 8). Jakarta: Pusat Studi Hukum Energi Dan Pertambangan.

Blomberg, A. A. (2009). The Intergration Of The Protection Of Nature Conservation Areas In Dutch Spatial Planning Law And Environmental Management Law. Utrecht Law Review .

Bppt, H. (2019). Cadangan Panas Bumi Di Indonesia Dalam Menghasilkan 27.000 Megawatt. Jakarta: Bppt Press.

Campbell, H. B. (1990). Black's Law Dictionary. St Paul Minn: West Publishing Co.

Conyers, D. (1992). Perencanaan Sosial Di Dunia Ketiga, Suatu Pengantar. Yogyakarta: Gadjah Mada University Press.

Damanik, I. (2020). Penyederhanaan Perizinan Usaha Di Daerah. Jakarta: Media. Neliti.

Durtge, H. T. (2014). Improving Environmental Permitting Systems: Integrated Permits In The Netherlands. International Public Administration Review Voll Xii Ed Ii .

Dwipa, S. (2018). Peluang Dan Tantangan Pengembangan Panas Bumi. Geominerba Journal .

Ebtke, H. (2020). Berikut Strategi Pemerintah Dalam Pengembangan Ebt Menuju Kemandirian Energi Nasional. Jakarta: Ditjen Ebtke.

Energy, B. G. (2019). Statistical Review Of World Energy. London.

Finahari, I. N. (2020). Pengembangan Panas Bumi Di Indonesia . Jakarta: Kesdm Press.

Finahari, I. N. (2020). Strategi Pemerintah Untuk Percepatan Pengembangan Panas Bumi. Jakarta: Kesdm Press.

Hadjon, P. M. (1993). Pengantar Hukum Perizinan. Surabaya: Yuridika.

Hamidi, J. (2009). Teori Dan Politik Hukum Tata Negara. Yogyakarta: Green 
Mind Community Total Media.

Hanggono, A. (2020). Perizinan Berusaha Berbasis Risiko . (Hal. 3). Jakarta: Kementerian Kelautan Dan Perikanan.

Heldeweg, M. (2012). Environmental Law In The Netherlands. Alphen Aan De Rijn: Wolter Kluwer.

Hr, R. (2014). Hukum Administrasi Negara . Jakarta: 2014.

Manan, B. (1994). Hubungan Antara Pusat Dan Daerah Menurut Uud 1945. Jakarta: Pustaka Sinar Harapan.

Nusantara, A. H. (1985). Politik Hukum Nasional. Yayasan Lbit Dan Lbh Surabaya .

Pindyck, R. S. (2001). Microeconomics. New York: Prentice Hall.

Radhie, M. T. (1973). Pembaharuan Dan Politik Hukum Dalam Rangka Pembangunan Nasional. Jurnal Prisma Nomor 6 Edisi Ii .

Shelton, A. K. (1997). Manual Of European Environmental Law. United Kingdom At The University Press .

Soekanto, S. (1999). Pokok-Pokok Sosiologi Hukum Edisi I Cet Ix. Jakarta: Raja Grafindo Persada.

Solihin, I. (2006). Pengantar Bisnis, Pengenalan Praktis Dan Studi Kasus. Jakarta: Kencana.

Sukhyar, R. (2019). Indonesia Sebagai Pusat Keunggulan Panas Bumi. Jakarta: Kesdm Press.

Sutedi, A. (2012). Hukum Pertambangan. Jakarta: Sinar Grafika.

Team, E. (2020). Geothermal Sumber Energi Terbarukan Untuk Masa Depan Indonesia. Jakarta: Esri.

Thohari, I. S. (2005). Dasar-Dasar Politik Hukum. Jakarta: Raja Grafindo Persada. Thomas, I. (2002). Environmental Impact Assessment In Australia Thery And Practice Third Edition. Australia: The Federation Press.

Trianto, W. (2019). Sumber Limbah Dan Potensi Pencemaran Penggunaan Geothermal Pada Pltp. Ejurnal Ppsdmmigas Vol 9 No 2.

Usman, E. (2020). Penanggulangan Krisis Dan Pengawasan Energi Dewan Energi Nasional Republik Indonesia. Jakarta: Dewan Energi Nasional.

Verrschuuren, J. (2004). Restructuring Environmental Legislation In The Netherlands. Environmental Law Network International Review.

Wijoyo, S. (2004). Penyelesaian Sengketa Lingkungan. Surabaya: Air Langga University Press.

Undang-Undang Nomor 11 Tahun 2020 Tentang Cipta Kerja Undang-Undang Nomor 21 Tahun 2014 Tentang Panas Bumi. 
UU No 31 Tahun 2009 Tentang Perlindungan dan Pengelolaan Lingkungan Hidup

Peraturan Pemerintah Nomor 24 Tahun 2018 Tentang Pelayanan Perizinan Berusaha Terintegrasi Secara Elektronik.

Peraturan Pemerintah Nomor 7 Tahun 2017 Tentang Panas Bumi Untuk Pemanfaatan Tidak Langsung.

Peraturan Menteri Energi Dan Sumber Daya Mineral Republik Indonesia Nomor 26 Tahun 2018 Tentang Pelaksanaan Kaidah Pertambangan Yang Baik Dan Pengawasan Pertambangan Mineral Dan Batu Bara 